\title{
KAJIAN KESEJAHTERAAN DI PROVINSI BENGKULU: SEBUAH TEMUAN DARI ANALISIS JALUR
}

\author{
Ratu Eva Febriani ${ }^{1)}$, Yusnida ${ }^{2)}$ \\ 1,2 Jurusan Ekonomi Pembangunan, Fakultas Ekonomi dan Bisnis, Universitas Bengkulu, Indonesia \\ ${ }^{1}$ ratuevafebriani@unib.ac.id, ${ }^{2}$ yusnida@unib.ac.id
}

\begin{abstract}
The paper conducts a quantitative appraisal of existing empirical testing on economic variable determinants of welfare in Bengkulu Province, analyze how economic growth dan income inequality affect welfare in Bengkulu Province directly or and using an intermediary variable. To capture this issue, path analysis is applied in this study as to the analysis method. The study addressed the measurement of the welfare of Bengkulu Province using the Human Development Index, and using the Williamson Index as representative of income inequality, also apply observational data for all variables in the period 2005-2017. The result shows that economic growth and income inequality to be associated with welfare in Bengkulu Province, and income inequality is proven an intervening variable affecting welfare.
\end{abstract}

Keywords : Welfare ${ }^{1}$, Economic Growth ${ }^{2}$, dan Income Inequality ${ }^{3}$

\section{PENDAHULUAN}

Kesejahteraan masyarakat merupakan tujuan utama dari pembangunan ekonomi disuatu wilayah. Oleh karenanya dalam proses pembangunan selalu diarahkan untuk mencapai kegiatan ekonomi yang tinggi dan terus menerus. Hal ini dilakukan karena indikator dari terwujudnya masyarakat yang sejahtera dapat dilihat dari meningkatnya pertumbuhan ekonomi dan meratanya distribusi pendapatan (Arsyad, 2010). Disamping itu, pembangunan yang lebih baik akan tercipta jika didukung oleh pemerintah daerah yang memiliki kapasitas untuk tampil secara efektif dalam pengelolaan sumber daya daerahnya (Oates,1993). Hal ini menunjukkan bahwa dengan kondisi geografis Indonesia yang terdiri dari banyak kepulauan akan menjadi sebuah hambatan besar dalam pemerataan pembangunan dan peningkatan kesejahteraan masyarakat. Oleh karenanya, penerapan kebijakan otonomi daerah merupakan terobosan penting untuk mewujudkan masyarakat yang sejahtera.

Gema kebijakan desentralisasi fiskal yang dipayungi oleh undang-undang mendorong berbagai daerah untuk dapat memajukan daerahnya. Tidak berbeda halnya dengan Provinsi Bengkulu, diawal pemerintahan hanya ada 4 kabupaten/kota yaitu Kota Bengkulu, Kabupaten Bengkulu Selatan, Kabupaten Rejang Lebong, dan Kabupaten 
Bengkulu Utara. Namun, dengan adanyanya kebijakan otonomi daerah maka saat ini Provinsi Bengkulu terdiri dari 10 kabupaten/kota, artinya telah terjadi pemekaran wilayah sebanyak 6 wilayah administratif baru yaitu Kabupaten Lebong, Kabupaten Kaur, Kabupaten Seluma, Kabupaten Muko-muko, Kabupaten Kepahiang, dan Kabupaten Bengkulu Tengah. Sesungguhnya pemekaran wilayah ini ditujukan untuk memaksimalkan kesejahteraan masyarakat lokal baik sebagai individu ataupun sebagai sebuah komunitas (Kuncoro, 2010). Kesejahteraan masyarakat di Provinsi Bengkulu dapat dilihat dari tiga aspek fundamental yaitu melalui kondisi tingkat pendidikan, kesehatan, dan standar kehidupan. Ketiga aspek ini merujuk pada pembangunan manusia yang ukurannya lebih dikenal dengan sebutan indeks pembangunan manusia (IPM). Tingkat pembangunan manusia akan sangat menentukan terhadap kemampuan penduduk dalam mengelola berbagai sumber daya untuk mendorong pertumbuhan ekonomi.

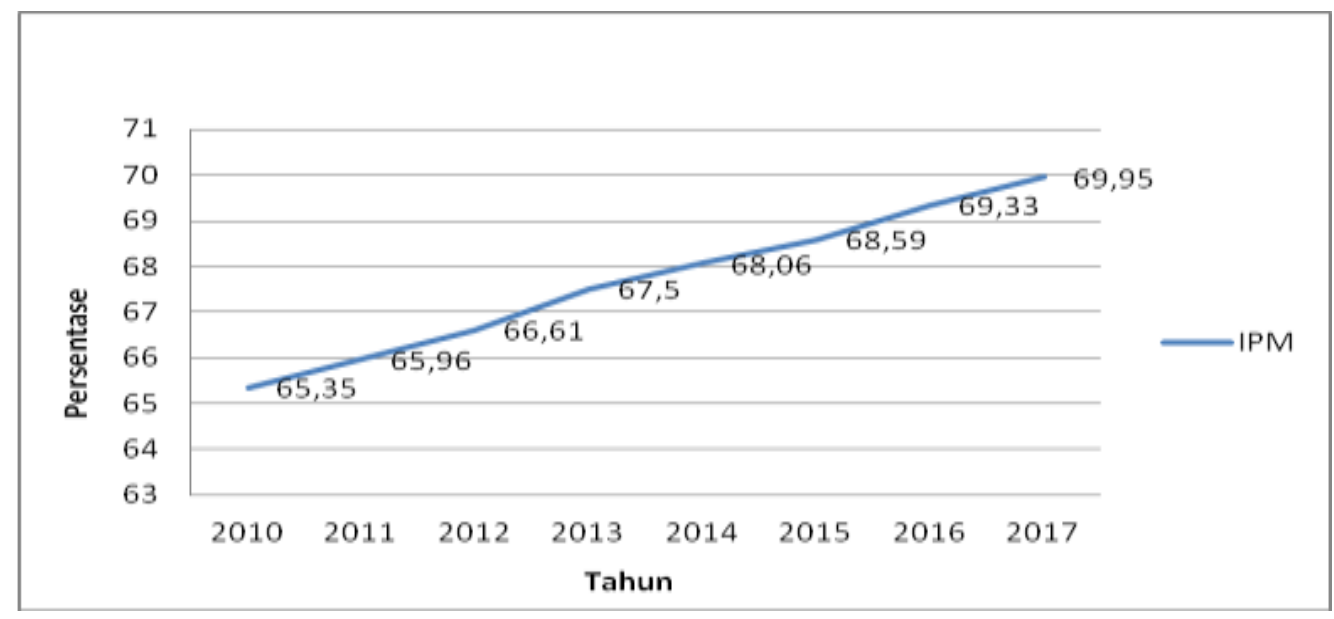

Grafik 1. Indeks Pembangunan Manusia Provinsi Bengkulu Tahun 2010-2017 Sumber: Badan Pusat Statistik Provinsi Bengkulu, 2017 (data diolah)

Berdasarkan data pada grafik 1 dapat diketahui bahwa perkembangan pembangunan manusia di Provinsi Bengkulu dalam kurun waktu 8 tahun relatif meningkat. Meskipun demikian, rata-rata pertumbuhan IPM masih dibawah angka 1\%, menunjukkan masih perlunya pemerintah Provinsi Bengkulu memberikan perhatian penuh dalam mengembangkan mutu modal manusia. Sementara, pergerakan pertumbuhan ekonomi Provinsi Bengkulu cenderung mengalami peningkatan terutama pada dua tahun terakhir (2015-2016). Pertumbuhan ekonomi menjelaskan kondisi ekonomi disuatu daerah atau negara, apakah dalam jangka waktu tertentu baik jangka pendek maupun jangka panjang telah terjadi perubahan yang fundamental didalam perekonomiannya atau belum. Secara 
umum, pertumbuhan ekonomi dijadikan alat ukur keberhasilan atau kemunduran perekonomian suatu daerah/negara yang merupakan indikator kesejahteraan masyarakat. Hal ini dikarenakan pertumbuhan ekonomi yang tinggi menunjukkan meningkatnya aktivitas ekonomi penduduk di suatu wilayah. Data pada tabel 1 menjelaskan bahwa pertumbuhan setiap daerah tidaklah sama, artinya dalam lingkup spasial pembangunan ekonomi tidak merata, ada daerah dengan pertumbuhan ekonomi yang cepat dan ada daerah dengan pertumbuhan ekonomi yang lambat.

Tabel 1. Pertumbuhan Ekonomi Kabupaten/Kota di Provinsi Bengkulu 2015-2017

\begin{tabular}{lccc}
\hline \multicolumn{1}{c}{ Kabupaten/Kota } & \multicolumn{3}{c}{ Tahun (\%) } \\
\cline { 2 - 4 } & $\mathbf{2 0 1 5}$ & $\mathbf{2 0 1 6}$ & $\mathbf{2 0 1 7} *$ \\
\hline Kota Bengkulu & 6,02 & 6,17 & 5,64 \\
Bengkulu Tengah & 5,01 & 5,04 & 5,02 \\
Kepahiang & 5,65 & 5,71 & 5,23 \\
Rejang Lebong & 5,15 & 5,27 & 5,01 \\
Lebong & 4,99 & 5,21 & 5,14 \\
Bengkulu Utara & 5,07 & 5,01 & 5,00 \\
Mukomuko & 5,54 & 5,69 & 5,31 \\
Seluma & 4,31 & 5,02 & 5,01 \\
Bengkulu Selatan & 5,14 & 5,32 & 5,01 \\
Kaur & 4,96 & 5,34 & 5,11 \\
\hline Provinsi Bengkulu & $\mathbf{5 , 1 3}$ & $\mathbf{5 , 2 8}$ & $\mathbf{4 , 9 8}$ \\
\hline
\end{tabular}

Sumber: BPS Provinsi Bengkulu, data diolah

Catatan: *) Angka sementara

Lebih lanjut, apabila membahas mengenai kesejahteraan penduduk, maka akan selalu diiringi dengan kondisi sebaliknya yaitu kemiskinan. Di Provinsi Bengkulu, jumlah persentase penduduk miskin di kabupaten/kota dalam kurun waktu 2015-2017 tercatat berfluktuasi. Meskipun kecenderungan pergerakan persentase penduduk miskin diberbagai kabupaten/kota di Provinsi Bengkulu cenderung menurun, namun pergerakannya relatif lambat dan masih berada diatas rata-rata angka persentase penduduk miskin nasional (lihat tabel 2).

Tabel 2. Persentase Penduduk Miskin Kabupaten/Kota di Provinsi Bengkulu Tahun 2015-2017

\begin{tabular}{lccc}
\hline \multirow{2}{*}{ Kabupaten/Kota } & \multicolumn{3}{c}{ Tahun } \\
\cline { 2 - 4 } & $\mathbf{2 0 1 5}$ & $\mathbf{2 0 1 6}$ & $\mathbf{2 0 1 7}$ \\
\hline Kota Bengkulu & 21,14 & 20,72 & 19,18 \\
Bengkulu Tengah & 8,33 & 8,71 & 8,41 \\
Kepahiang & 16,83 & 16,31 & 15,95
\end{tabular}




\begin{tabular}{lrrr}
\hline \multicolumn{1}{c}{ Kabupaten/Kota } & \multicolumn{3}{c}{ Tahun } \\
\cline { 2 - 4 } \multicolumn{1}{c}{ Rejang Lebong } & $\mathbf{2 0 1 5}$ & $\mathbf{2 0 1 6}$ & $\mathbf{2 0 1 7}$ \\
\hline Lebong & 18,03 & 17,81 & 16,97 \\
Bengkulu Utara & 12,32 & 12,26 & 11,83 \\
Mukomuko & 14,78 & 13,67 & 13,11 \\
Seluma & 13,45 & 13,01 & 12,20 \\
Bengkulu Selatan & 22,98 & 21,68 & 20,73 \\
Kaur & 22,76 & 22,10 & 21,06 \\
\hline Provinsi Bengkulu & 22,87 & 22,36 & 21,54 \\
\hline
\end{tabular}

Sumber : BPS Provinsi Bengkulu (2019)

Berdasarkan tabel 2, jika ditinjau per kabupaten/kota yang ada di Propinsi Bengkulu, Kabupaten Kaur merupakan kabupaten dengan jumlah persentase penduduk miskin terbanyak dengan jumlah rata-rata penduduk miskin selama 3 tahun terakhir yaitu sebesar 22.26 persen, sedangkan kabupaten dengan persentase penduduk miskin yang paling rendah adalah Bengkulu Tengah yaitu sebesar 8,48 persen atau terdapat selisih sebesar 13,77 persen. Keadaan ini secara tidak langsung menunjukkan adanya ketimpangan tingkat kesejahteraan masyarakat di Provinsi Bengkulu.

Tabel 3. PDRB Per Kapita Kabupaten/Kota di Provinsi Bengkulu Tahun 2012-2015

\begin{tabular}{lcccc}
\hline \multirow{2}{*}{ Kab/Kota } & \multicolumn{4}{c}{ PDRB Perkapita (Rp.) } \\
\cline { 2 - 5 } & $\mathbf{2 0 1 2}$ & $\mathbf{2 0 1 3}$ & $\mathbf{2 0 1 4}$ & $\mathbf{2 0 1 5}$ \\
\hline Bengkulu Selatan & 19.463 .962 & 21.667 .763 & 24.049 .573 & 26.536 .354 \\
Rejang Lebong & 19.062 .502 & 21.122 .316 & 23.375 .957 & 25.854 .784 \\
Bengkulu Utara & 15.265 .932 & 16.702 .124 & 18.297 .475 & 19.955 .154 \\
Kaur & 15.390 .964 & 16.960 .161 & 18.412 .293 & 20.256 .155 \\
Seluma & 12.836 .325 & 14.249 .139 & 15.736 .535 & 17.232 .892 \\
Muko-muko & 15.547 .108 & 16.960 .317 & 18.687 .530 & 20.126 .227 \\
Lebong & 16.013 .118 & 17.633 .415 & 19.461 .452 & 21.343 .277 \\
Kepahiang & 16.518 .310 & 18.240 .883 & 20.122 .627 & 22.292 .524 \\
Bengkulu Tengah & 22.824 .964 & 25.072 .743 & 27.846 .241 & 30.485 .275 \\
Kota Bengkulu & 34.833 .303 & 37.994 .744 & 41.386 .320 & 45.020 .681 \\
Provinsi Bengkulu & 20.298 .912 & 22.358 .053 & 24.605 .949 & 26.849 .718 \\
\hline
\end{tabular}

Sumber : BPS Provinsi Bengkulu (2015)

Dari sisi pendapatan per kapita di Provinsi Bengkulu (lihat tabel 3), jika kita bandingkan antara pendapatan rata-rata Provinsi Bengkulu dengan seluruh kabupaten/kota selama tahun 2012-2015 terdapat 8 Kabupaten yang memiliki pendapatan perkapita di bawah pendapatan perkapita Provinsi Bengkulu, sementara itu ada 2 kabupaten/kota berada di 
atas pendapatan perkapita Provinsi Bengkulu. Data tersebut mengindikasikan bahwa terjadinya ketimpangan pendapatan yang dirasakan oleh seluruh penduduk Provinsi Bengkulu, artinya ini menunjukkan adanya perbedaan capaian tingkat kesejahteraan yang dinikmati oleh masyarakat Provinsi Bengkulu. Padahal pemerataan distribusi pendapatan merupakan hal yang penting dalam pembangunan daerah karena ketimpangan pendapatan akan berpengaruh buruk terhadap pertumbuhan ekonomi dan berdampak pada penurunan kesejahteraan masyarakat suatu wilayah. Olehkarena itu maka studi ini bertujuan: (1) Mengetahui tingkat ketimpangan pendapatan antar daerah di Provinsi Bengkulu, (2) Mengetahui pengaruh pertumbuhan ekonomi, ketimpangan pendapatan antar daerah terhadap kesejahteraan masyarakat Provinsi Bengkulu baik secara sendiri-sendiri maupun secara gabungan, dan (3) Mengetahui pengaruh tidak langsung pertumbuhan ekonomi terhadap kesejahteraan masyarakat melalui ketimpangan pendapatan antardaerah.

\section{TINJAUAN PUSTAKA}

\section{Konsep Kesejahteraan Masyarakat}

Pada awal perkembangannya, keadaan kehidupan manusia dalam hal kegiatan ekonomi diukur melalui pendekatan konsep utilitas. Setiap manusia pada dasarnya melakukan berbagai kegiatan ekonomi untuk memaksimalkan tingkat kepuasannya (util). Konsep yang dikembangkan oleh aliran neoklasik ini lebih menekankan pada pencapaiannya dalam bentuk uang atau lebih spesifiknya sebagai pendapatan nasional per kapita. Sesungguhnya konsep ini tidak dapat diterapkan secara mutlak sebagai indikator yang mencerminkan kesejahteraan sebuah negara penuh. Hal ini dikarenakan secara statistik penggunaan pendapatan perkapita sebagai sebuah indeks kesejahteraan masyarakat memiliki kelemahan. Oleh karenanya maka pada tahun 1990, United Nations Development Program (UNDP) merombak teori pembangunan, cara pengukuran, dan kebijakan dengan mempublikasikannya pada laporan tahunan pertamanya mengenai pembangunan manusia dan memperkenalkan konsep pengukuran kesejahteraan yang baru yaitu Human Development Index (HDI).

Human Development Index atau di Indonesia lebih umum dikenal dengan indeks pembangunan manusia (IPM) dikembangkan oleh pemenang nobel Amartya Sen dan Mahbub ul Haq (ekonom pakistan) serta dibantu oleh ekonom dari Yale University yaitu Gustav Ranis. IPM merupakan indeks komposit yang digunakan untuk mengukur 
kesejahteraan antarnegara ataupun antardaerah (Todaro, 2012). Indeks ini mengukur pembangunan sosial ekonomi nasional berdasarkan kombinasi pengukuran dari pendidikan, kesehatan, dan penyesuaian pendapatan per kapita riil. Dalam indeks pembangunan manusia terdapat tiga komposisi indikator yang digunakan yaitu: (Todaro, 2012)

1. Tingkat kesehatan diukur dengan harapan hidup saat lahir $\left(\mathrm{X}_{1}\right)$.

2. Tingkat pendidikan diukur dengan rata-rata angka melek huruf penduduk dewasa (dua pertiga) dan rasio lama sekolah (sepertiga) $\left(\mathrm{X}_{2}\right)$.

3. Standar kehidupan diukur dengan tingkat pendapatan per kapita per tahun $\left(\mathrm{X}_{3}\right)$.

Secara matematis IPM dapat dirumuskan sebagai berikut:

$$
\mathrm{IPM}=\frac{1}{3}\left(X_{1}+X_{2}+X_{3}\right)
$$

BPS Provinsi Bengkulu mengklasifikasikan tingkatan IPM menjadi 4 golongan, antara lain IPM rendah ( kurang dari 60), IPM sedang (60-70), IPM tinggi (71-79) dan IPM tinggi (diatas 80).

\section{Ketimpangan Pendapatan}

Kuznet (1955) mengkaji karakter dan penyebab perubahan jangka panjang terhadap distribusi pendapatan individu. Apakah ketimpangan pada distribusi pendapatan meningkat atau menurun terkait dengan pertumbuhan ekonomi suatu negara? Dari hasil penelusuran secara empiris, Kuznet menemukan adanya sebuah pola yang berbentuk U terbalik terkait dengan ketimpangan antardaerah. Pola ini menunjukkan bahwa pada tahap awal pembangunan, proses pertumbuhan ekonomi akan diikuti oleh memburuknya distribusi pendapatan dan sampai pada titik tertentu, arah hubungan akan terbalik dimana pembangunan akan diikuti oleh pemerataan yang lebih baik.

Sementara, dalam teori neoklasik dikemukakan bahwa distribusi faktor produksi seperti modal dan tenaga kerja, pada tahap awal pembangunan yang kurang lancar, akan menyebabkan modal dan tenaga kerja terkonsentrasi pada daerah tertentu yang menyebabkan kesenjangan pembangunan cenderung meningkat. Namun, apabila proses pembangunan berlangsung secara terus-menerus atau berkelanjutan, sehingga semakin membaiknya prasarana dan fasilitas komunikasi maka distribusi modal dan tenaga kerja tersebut akan semakin lancar. Membaiknya distribusi pendapatan akan meningkatkan 
kesejahteraan masyarakat, artinya kesenjangan pembangunan daerah semakin berkurang (Sjafrizal, 2008).

\section{Pertumbuhan Ekonomi}

Menurut Kuznet dalam Todaro (2012) yang dimaksud dengan pertumbuhan ekonomi adalah kenaikan kapasitas produksi dalam jangka panjang dari suatu negara atau daerah untuk menyediakan berbagai barang ekonomi kepada penduduknya. Kemampuan ini tumbuh berdasarkan kemajuan teknologi, institusional, dan ideologi yang diperlukan. Todaro (2012) menyatakan bahwa ada tiga faktor utama dalam pertumbuhan ekonomi yaitu:

1. Akumulasi modal, meliputi semua bentuk faktor produksi yaitu peralatan fisik, modal, pabrik, bangunan, tanah, dan sumber daya manusia.

2. Pertumbuhan penduduk, jumlah dan perkembangan penduduk berhubungan erat dengan perannya sebagai tenaga kerja.

3. Kemajuan teknologi, penerapan metode baru dalam melakukan produksi yang dapat meningkatkan output secara nasional.

Laju pertumbuhan ekonomi dapat cari dengan menggunakan rumus berikut (Arsyad, 2010):

$$
G T=\frac{Y_{r t}-Y_{r t-1}}{Y_{r t-1}} X 100 \%
$$

Keterangan:

$\mathrm{Gt}=$ Tingkat pertumbuhan ekonomi $(\%)$

$\mathrm{Y}_{\mathrm{rt}}=$ Produk Domestik Regional Bruto riil tahun $\mathrm{t}$

$\mathrm{Y}_{\mathrm{rt}-1}=$ Produk Domestik Regional Bruto riil tahun sebelumnya

Pertumbuhan ekonomi berhubungan dengan ketimpangan pendapatan. Hal ini dinyatakan oleh Kuznet (Todaro, 2012) yang menerangkan bahwa dalam jangka pendek ada korelasi positif, namun hubungan ini berubah menjadi negatif ketika dalam jangka panjang. Konsep yang dikemukakan oleh Kuznet ini dikenal sebagai konsep $U$-shaped terbalik. Artinya dalam tahap awal pembangunan tingkat ketimpangan akan semakin besar sampai pada tingkat tertentu dan selanjutnya tingkat ketimpangan tersebut akan semakin berkurang. 
Sementara itu sebagai bagian dari variabel makroekonomi, pertumbuhan ekonomi memiliki dampak kuat pada kesejahteraan masyarakat. Hal ini diperkuat dengan pernyataan oleh UNDP (2000) bahwa sampai akhir tahun 1990-an, kesejahteraan masyarakat yang dilihat dari pembangunan manusianya ditentukan oleh pertumbuhan ekonomi. Pertumbuhan ekonomi mendorong terjadinya peningkatan pendapatan yang menyebabkan kemampuan masyarakat dalam memenuhi kebutuhannya menjadi lebih baik.

\section{Penelitian Terdahulu}

Para ahli ekonomi diberbagai dunia banyak melakukan kajian mengenai ketimpangan pendapatan dan juga dampaknya terhadap kesejahteraan masyarakat. Lanjouw, dkk (2012) menyatakan bahwa pembangunan manusia di Indonesia identik dengan pengurangan kemiskinan yang mengarah pada peningkatan pendapatan. Hal ini disebabkan penduduk miskin sangat bergantung pada kemampuan fisik mereka sebagai aset utama yang dimiliki. Oleh karenanya maka investasi dibidang pendidikan dan kesehatan akan lebih berarti bagi penduduk miskin dibandingkan penduduk tidak miskin. Di sisi lain, pergerakan GDP per kapita sebagai indikator dari pertumbuhan ekonomi dianalisis sebagai sebuah faktor dari ketimpangan pendapatan.

Chang dan Ram (2000) mengemukakan bahwa pertumbuhan ekonomi yang cepat yang meliputi aktivitas kewiraurahaan memusatkan pendapatan pada orang-orang kaya yang mampu melakukan investasi dan mendapatkan manfaat dari pertumbuhan ekonomi. Dengan menggunakan data cross-section tahun 1980an menunjukkan bahwa pertumbuhan ekonomi yang cepat menyebabkan penurunan ketimpangan pendapatan. Sementara penelitian yang dilakukan oleh Xu dan Zou (2000) dengan menggunakan data di China, menghasilkan bukti empiris bahwa pertumbuhan ekonomi meningkatkan ketimpangan pendapatan. Menggunakan prosedur estimasi berupa regresi OLS, Sarel (1997) mengkaji hubungan antara variabel makroekonomi dan kecenderungan pada distribusi pendapatan. Hasil temuannya menjelaskan bahwa variabel makroekonomi yang berkaitan dengan peningkatan pada distribusi pendapatan adalah tingkat pertumbuhan ekonomi yang tinggi, pendapatan yang tinggi, investasi yang besar, dan peningkatan pada terms of trade. Pertumbuhan ekonomi yang tinggi mendorong peningkatan pada akses ekonomi masyarakat sehingga meningkatkan kesejahteraan masyarakat secara aggregat. Namun, 
dari hasil penelitian tersebut juga di duga secara kuat bahwa sebagian kecil dari populasi yang secara relatif lebih menikmati pertumbuhan ekonomi.

\section{Kerangka Konseptual Penelitian}

Pada umumnya, negara didunia meninjau capaian pembangunan ekonominya dengan menggunakan variabel makroekonomi berupa pertumbuhan ekonomi dan distribusi pendapatan. Secara tidak langsung dapat dikatakan bahwa variabel makroekonomi memiliki kaitan erat dengan perwujudan kesejahteraan masyarakat disuatu negara. Hubungan antara pertumbuhan ekonomi dan kesejahteraan masyarakat perlu dikaji secara empiris agar dapat dimengerti bagaimana sifat dari hubungan tersebut, apakah mereka berpengaruh secara langsung atau tidak langsung melalui variabel intermediasi. Oleh sebab itu, dalam penelitian ini akan dikaji bagaimana pertumbuhan ekonomi secara langsung berpengaruh terhadap kesejahteraan masyarakat di Provinsi Bengkulu. Selain itu, pengaruh tidak langsung akan pula dikaji dengan menggunakan ketimpangan pendapatan sebagai variabel intervening terhadap kesejahteraan masyarakat di Provinsi Bengkulu. Pemilihan Provinsi Bengkulu sebagai objek daerah penelitian dilandaskan pada karakteristiknya sebagai daerah yang terkategori miskin diantara 33 propinsi lainnya, sementara dari sisi pertumbuhan ekonominya berada diatas rata-rata pertumbuhan nasional.

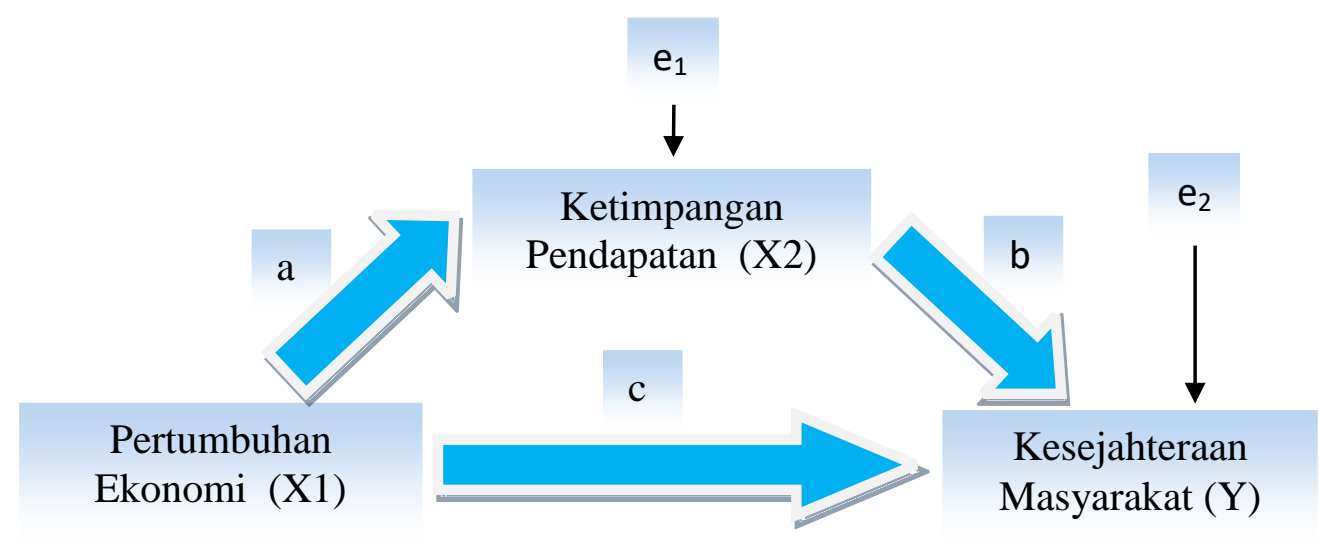

Gambar 1. Kerangka Konseptual Penelitian

\section{METODE PENELITIAN}

Penelitian ini menggunakan data pertumbuhan ekonomi, data indeks williamson, dan data IPM yang berada pada periode 2005-2017 di Provinsi Bengkulu. Pengujian pengaruh antar variabel akan dilakukan dengan menggunakan metode analsis jalur (Path Analysis). 
Analisis jalur merupakan pengembangan korelasi yang diuraikan menjadi beberapa interpretasi dari akibat yang ditimbulkannya. Asal muasal analisis ini bersumber dari buah pikiran dari seorang ahli genetika bernama Sewall Wright. Dia mengembangkan metode analisis ini untuk membuat kajian hipotesis hubungan sebab akibat dengan menggunakan korelasi. Teknik ini dikenal sebagai model sebab-akibat, penamaannya sebagai path analysis berdasarkan alasan bahwa analisis jalur memungkinkan pengguna dapat menguji preposisi teoritis tentang hubungan sebab-akibat tanpa memanipulasi variabel-variabel. Path analysis memiliki kedekatan dengan analisis regresi berganda, sehingga dalam penerapannya asumsi dasar yang digunakan dalam regresi berganda juga diterapkan dalam Path analysis.

Apa sesungguhnya Path analysis? Banyak literatur yang memberikan defenisi terkait dengan analisis jalur ini, namun disini akan diterangkan beberapanya saja. Menurut Streiner (2005), Analisis jalur adalah sebuah bentuk perluasan dari regresi berganda yang memungkinkan untuk melakukan analisa model-model yang lebih kompleks. Sementara menurut Sarwono (2011) yang dimaksud dengan path analysis adalah teknik analisis yang digunakan untuk menganalisis hubungan sebab akibat yang inheren antar variabel yang di susun berdasarkan urutan temporer dengan menggunakan koefisien jalur sebagai besaran nilai dalam menentukan besarnya pengaruh variabel independen exogeneous terhadap variabel dependen endogeneous.

Meskipun analisis jalur berkaitan dengan analisis regresi, namun pada penerapannya, kedua metode ini berbeda. Perbedaan tersebut terkait dengan pola hubungan yang ingin dijelaskan. Pada analisis regresi, hubungan antar variabel yang diuji terbatas pada pendugaan pengaruh variabel penentu (misal; $\mathrm{x}_{1}, \mathrm{x}_{2}, \mathrm{x}_{3}, \ldots ., \mathrm{x}_{\mathrm{t}}$ ) dengan variabel respon (misal; Y). Peramalan atau pendugaan nilai variabel respon (Y) akibat dari variabel penentu (X) mengisyaratkan pengaruh baik secara individual maupun bersamaan. Sementara, secara matematik, analisis jalur lebih mengarah pada model hubungan sebab akibat atau model struktural (Riduwan \& Engkos, 2008).

Berdasarkan pada gambar 1, maka dapat dibuat persamaan struktural sebagai berikut:

$\mathrm{X}_{2}=\beta_{1} \mathrm{X}_{1}+\mathrm{e}_{1}$

$Y=\beta_{2} X_{1}+\beta_{3} X_{2}+e_{2}$ 
Keterangan:

$\mathrm{Y} \quad=$ Kesejahteraan masyarakat

$\mathrm{X}_{1} \quad=$ Pertumbuhan Ekonomi

$\mathrm{X}_{2} \quad=$ Ketimpangan Pendapatan Antardaerah

$\beta_{1}, \beta_{2}, \beta_{3}=$ Koefisien regresi untuk masing-masing variabel $\mathrm{X}$

\section{HASIL DAN PEMBAHASAN}

\section{Uji asumsi klasik}

Meskipun yang digunakan dalam penelitian ini adalah analisis jalur, namun pengoperasian teknisnya masih sama seperti penerapan model regresi berganda. Oleh karenanya agar hasil dari model ini dapat dinilai valid, maka harus lulus persyaratan dasar. Persyaratan tersebut adalah harus lolos uji asumsi klasik. Uji asumsi klasik yang dilakukan adalah uji normalitas, uji multikolinieritas, uji heteroskedastisitas, dan uji autokorelasi.

Tabel 4. Hasil Uji Asumsi Klasik

\begin{tabular}{|c|c|c|c|c|}
\hline$\underbrace{\text { Uji asumsi klasik }}_{\text {Kriteria Uji }}$ & Normalitas & Multikolinieritas & Heteroskedastisitas & Autokorelasi \\
\hline Kolmogorov-Smirnov Z & 0,565 & & & \\
\hline Asymp. Sig. (2-tailed) & 0,906 & & & \\
\hline $\begin{array}{l}\text { Tolerance Pertumbuhan } \\
\text { Ekonomi }\end{array}$ & & 0,996 & & \\
\hline $\begin{array}{l}\text { Tolerance Ketimpangan } \\
\text { Pendapatan }\end{array}$ & & 0,966 & & \\
\hline $\begin{array}{l}\text { VIF Pertumbuhan } \\
\text { ekonomi \& } \\
\text { ketimpangan } \\
\text { pendapatan }\end{array}$ & & 1,004 & & \\
\hline $\begin{array}{l}\text { Signifikansi nilai t- } \\
\text { statistik pertumbuhan } \\
\text { ekonomi }\end{array}$ & & & 0,600 & \\
\hline $\begin{array}{l}\text { Signifikansi nilai t- } \\
\text { statistik ketimpangan } \\
\text { pendapatan }\end{array}$ & & & 0,254 & \\
\hline Durbin-Watson & & & & 1.185 \\
\hline
\end{tabular}

Sumber: Hasil olah data, 2019

Informasi yang tertera pada tabel 4 menunjukkan bahwa setelah dilakukan uji asumsi klasik ditemukan bahwa model terbukti valid. Dari uji normalitas dengan pendekatan uji 
Kolmogorov-Smirnov diperoleh nilai KSZ sebesar 0,565 dan Asymp.sig sebesar 0,906 lebih besar dari 0,05 maka disimpulkan bahwa data berdistribusi normal. Untuk uji multikolinieritas, diketahui nilai tolerance dari masing-masing variabel adalah kurang dari 1 dan nilai VIF dari masing-masing variabel adalah kurang dari 10 maka dapat dikatakan bahwa dalam model regresi ini tidak terjadi multikolinieritas pada ketiga variabel bebas tersebut. Selanjutnya, dari hasil uji Glejser, nilai signifikansi dari masing-masing variabel lebih besar dari nilai alpha maka dapat dinyatakan bahwa model tidak mengalami masalah heteroskedastisitas. Sementara, melalui uji Durbin Watson \{dengan alpha 5 persen, jumlah sampel $(n)=13$, dan jumlah variabel bebas $(k)=2$ diperoleh nilai $d_{U}=1,562, d_{L}=0,861$, $4-\mathrm{d}_{\mathrm{U}}=(4-1,562)=2,438$, dan $\left.4-\mathrm{d}_{\mathrm{L}}=(4-0,861)=3,139\right\}$ diketahui bahwa nilai DW berada diantara nilai du dan $4-\mathrm{d}_{\mathrm{U}}$, artinya berada didaerah tidak ada autokorelasi. Jadi dapat dipastikan bahwa dalam model ini tidak terjadi autokorelasi.

\section{Uji Hipotesis Koefisien Jalur}

Untuk mengetahui pengaruh antara variabel independen terhadap variabel dependen maka dilakukan uji t. Pengujian ini sifatnya dua arah, sebab preposisi hipotesa yang dituliskan sebelumnya tidak mengisyaratkan bentuk pengaruh antar variabel berupa pengaruh positif atau negatif. Dengan menggunakan output SPSS 16, ditabel koefisien, pada kolom signifikan dan t dipakai untuk menguji koefisien jalur.

$>$ Koefisien jalur $\rho \mathrm{YX}_{1}$

$$
\begin{aligned}
& \mathrm{H} 0: \rho \mathrm{YX}_{1}=0 \\
& \mathrm{H} 1: \rho \mathrm{YX}_{1} \neq 0
\end{aligned}
$$

Berdasarkan hasil pada tabel 5.9, terlihat p-value (kolom sig.) = 0,001 yang lebih kecil dari 0,05 atau pada kolom $\mathrm{t}=-4,35$ yang lebih besar dari titik kritis $-1,795$. Dengan menggunakan tingkat $\alpha$ sebesar 5\% maka ditetapkan bahwa $\mathrm{H}_{0}$ ditolak.

\section{Koefisien jalur $\rho \mathrm{YX}_{2}$}

$\mathrm{H} 0: \rho \mathrm{YX}_{2}=0$

$\mathrm{H} 1: \rho \mathrm{YX}_{2} \neq 0$

Berdasarkan hasil pada tabel 5.9, terlihat p-value (kolom sig.) = 0,012 yang lebih kecil dari 0,05 atau pada kolom $\mathrm{t}=-4,359$ yang lebih besar dari titik kritis 1,795 . Dengan menggunakan tingkat $\alpha$ sebesar 5\% maka ditetapkan bahwa $\mathrm{H}_{0}$ ditolak. 
Tabel 5. Nilai Koefisien

\begin{tabular}{|c|c|c|c|c|c|}
\hline \multirow[t]{2}{*}{ Model } & \multicolumn{2}{|c|}{$\begin{array}{r}\text { Unstandardized } \\
\text { Coefficients }\end{array}$} & \multirow{2}{*}{$\begin{array}{c}\text { Standardized } \\
\text { Coefficients } \\
\text { Beta }\end{array}$} & \multirow[t]{2}{*}{$\mathrm{t}$} & \multirow[t]{2}{*}{ Sig. } \\
\hline & $\mathrm{B}$ & Std. Error & & & \\
\hline 1 (Constant) & 85,352 & 3,407 & & 25.056 & 0,000 \\
\hline $\begin{array}{l}\text { Pertumbuhan } \\
\text { Ekonomi }\end{array}$ & $-1,774$ & 0,407 & $-0,690$ & $-4,359$ & 0,001 \\
\hline $\begin{array}{l}\text { Ketimpangan } \\
\text { Pendapatan }\end{array}$ & $-20,542$ & 6,712 & $-0,484$ & $-3,060$ & 0,012 \\
\hline
\end{tabular}

Sumber: Hasil Olah Data, 2019.

Berdasarkan hasil uji hipotesa maka dapat dinyatakan bahwa pertumbuhan ekonomi dan ketimpangan pendapatan berpengaruh signifikan terhadap kesejahteraan masyarakat Provinsi Bengkulu. Dari tabel 5 diketahui bahwa koefisien jalur $X_{1}$ dan $X_{2}$ adalah -0,690 dan $-0,484$, keduanya signifikan. Selanjutnya, nilai $\mathrm{R}$ square sebesar 0,751 , dengan demikian koefisien jalur $\varepsilon$ (variabel diluar model) adalah:

$$
\rho_{\mathrm{y \varepsilon}}=\sqrt{1-0,751}=0,249
$$

Hal selanjutnya yang harus dilakukan dalam menentukan jalur pengaruh antar variabel adalah melakukan pengujian korelasi antar variabel tersebut. Dari hasil pengujian yang dilakukan didapatkan hasil sebagaimana yang tertera pada tabel 6.

Tabel 6. Koefisien Korelasi antar Variabel

\begin{tabular}{lccc}
\hline Variabel & X1 & X2 & Y \\
\hline Pertumbuhan Ekonomi (X1) & 1 & 0,061 & $-0,719^{* * *}$ \\
Ketimpangan Pendapatan (X2) & 0,061 & 1 & $-0,526^{*}$ \\
Kesejahteraan Masyarakat (Y) & $-0,719^{* * *}$ & $-0,526^{*}$ & 1
\end{tabular}

Sumber: Hasil olah data, 2018

Keterangan: *** Korelasi signifikan pada level 0,01 (2-tailed)

* Korelasi signifikan pada level 0,1 (2-tailed)

Dengan demikian maka pendekatan analisis jalur untuk model ini dapat diuraikan sebagai berikut:

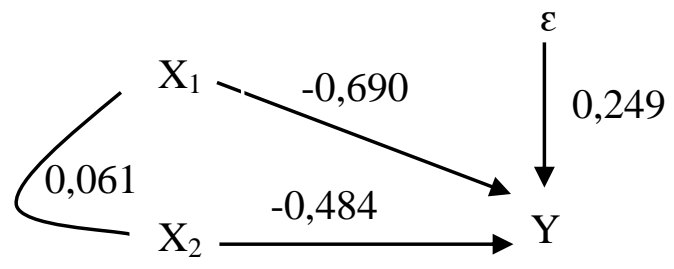

Gambar 2. Sï̌ükïüi Hubungan Kausal dari $X_{1}$ dan $X_{2}$ ke $Y$ 


\section{Besarnya pengaruh secara proporsional}

\section{- Pengaruh $\mathbf{X}_{1}$}

Pengaruh langsung

$$
\begin{aligned}
& =\rho \mathrm{yx}_{1} \times \rho \mathrm{yx}_{1} \\
& =(-0,690)(-0,690) \\
& =0,476
\end{aligned}
$$

Pengaruh melalui hubungan korelatif dengan $\mathrm{X} 2=\rho \mathrm{yx}_{1} \mathrm{x} \mathrm{rx}_{1} \mathrm{x}_{2} \mathrm{x} \rho \mathrm{yx}_{2}$

$$
\begin{aligned}
& =(-0,690)(0,061)(-0,484) \\
& =0,020 \\
& =0,476+0,020 \\
& =0,496
\end{aligned}
$$

Pengaruh X1 ke Y secara total

\section{- Pengaruh $\mathrm{X}_{2}$}

Pengaruh langsung

$$
\begin{aligned}
& =\rho \mathrm{yx}_{2} \mathrm{x} \rho \mathrm{yx}_{2} \\
& =(-0,484)(-0,484) \\
& =0,234
\end{aligned}
$$

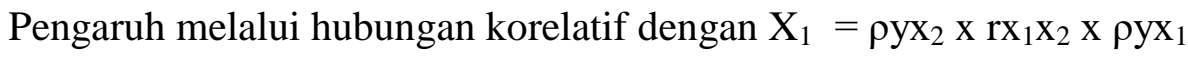

Pengaruh $\mathrm{X}_{2}$ ke $\mathrm{Y}$ secara total

$$
\begin{aligned}
& =(-0,484)(0,061)(-0,690) \\
& =0,020 \\
& =0,234+0,020 \\
& =0,255
\end{aligned}
$$

Pengaruh gabungan oleh $\mathrm{X} 1$ dan $\mathrm{X} 2$ ke $\mathrm{Y}$ adalah $0,496+0,255=0,751$, yang tidak lain adalah besarnya $\mathrm{R}^{2} \mathrm{y}\left(\mathrm{x}_{1} \mathrm{x}_{2}\right)=0,751$.

\section{Ketimpangan Pendapatan Antardaerah Provinsi Bengkulu}

Provinsi Bengkulu memiliki luas sebesar 34.724,69 $\mathrm{km}^{2}$ dengan luas daratan 19.795,15 $\mathrm{km}^{2}$ dan luas lautan 14.929,54 km² (Bakorsutanal, 2010). Secara administratif, Provinsi Bengkulu terdiri dari 9 (sembilan) Kabupaten dan 1 (satu) Kota, 128 kecamatan dan 1.515 desa. Setiap Kabupaten/Kota di Provinsi Bengkulu memiliki luas wilayah yang berbeda. dan diikuti dengan karakteristikwilayah yang berbeda pula. 
Grafik 2. Luas Wilayah Provinsi Bengkulu Menurut Kabupaten/Kota

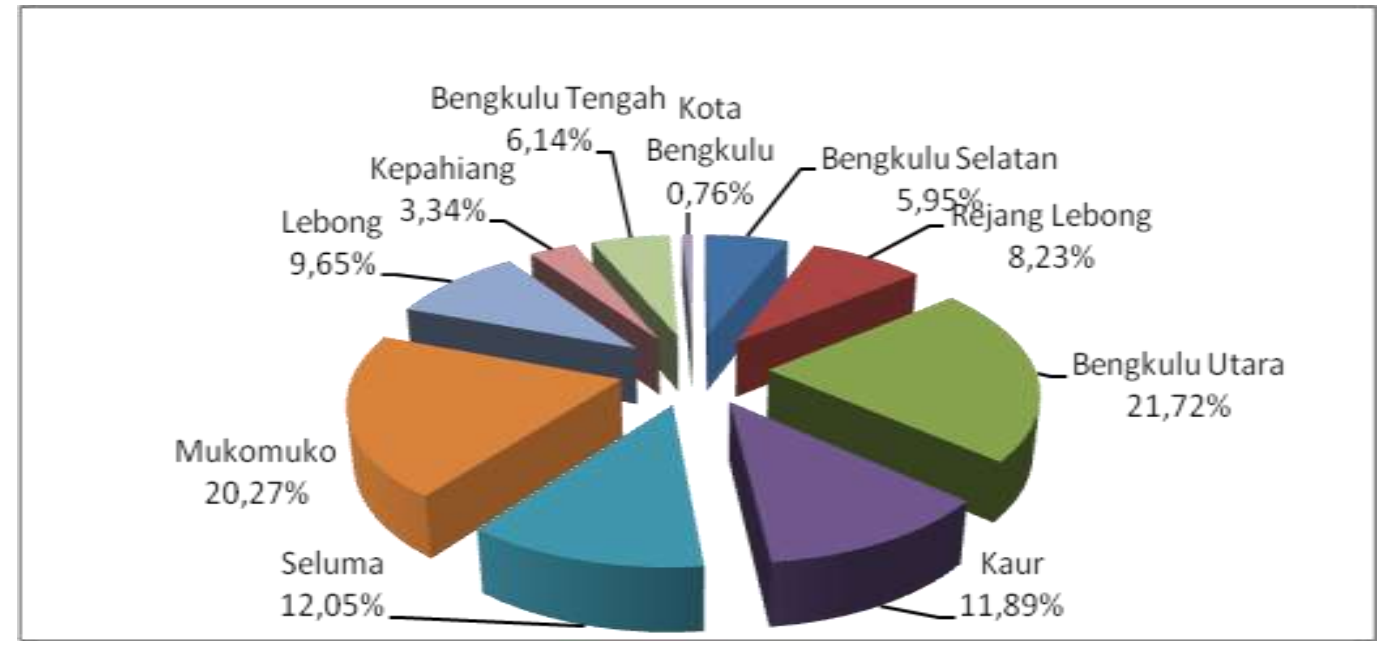

Sumber: Provinsi Bengkulu Dalam Angka 2017 (BPS Provinsi Bengkulu, data diolah)

Perbedaan karakteristik wilayah berupa sumber daya alam merupakan salah satu faktor yang mendorong terjadinya ketimpangan pembangunan selain dari faktor lainnya seperti sumber daya manusia, sumber daya sosial, sumber daya buatan (ketersediaan sarana dan prasarana sosial-ekonomi), karakteristik ekonomi wilayah, dan kebijakan pemerintah daerah (Anwar, 2005).

Seiring gencarnya pembangunan di suatu wilayah maka akan diikuti oleh ketimpangan pembangunan. Fenomena ini menunjukkan bahwa dalam proses pembangunan yang bersifat spasial masalah ketimpangan akan muncul. Kondisi ini menunjukkan terjadinya perbedaan tingkat pembangunan dan tingkat kesejahteraan pada suatu wilayah, beberapa wilayah mencapai pertumbuhan ekonomi yang cepat sementara dibeberapa wilayah lainnya mengalami pertumbuhan yang lambat.

Ketimpangan pembangunan dalam suatu wilayah dapat diidentifikasi dengan menggunakan indeks williamson. Indeks ini secara perhitungannya berbasiskan pada pendapatan perkapita dan jumlah penduduk. Artinya indeks ini mengukur seberapa besar ketimpangan pendapatan yang terjadi antar daerah dalam suatu provinsi atau negara. Untuk Provinsi Bengkulu, ketimpangan pendapatan antar daerah yang terjadi dalam kurun waktu 13 tahun terakhir berfluktuasi dengan tren yang menurun. Meskipun trennya menurun namun secara rata-rata nilai indeks williamson di Provinsi Bengkulu masih berada dalam kategori ketimpangan sedang yaitu sebesar 0,383. 
Grafik 3. Indeks Williamson Propinsi Bengkulu Periode 2005-2017

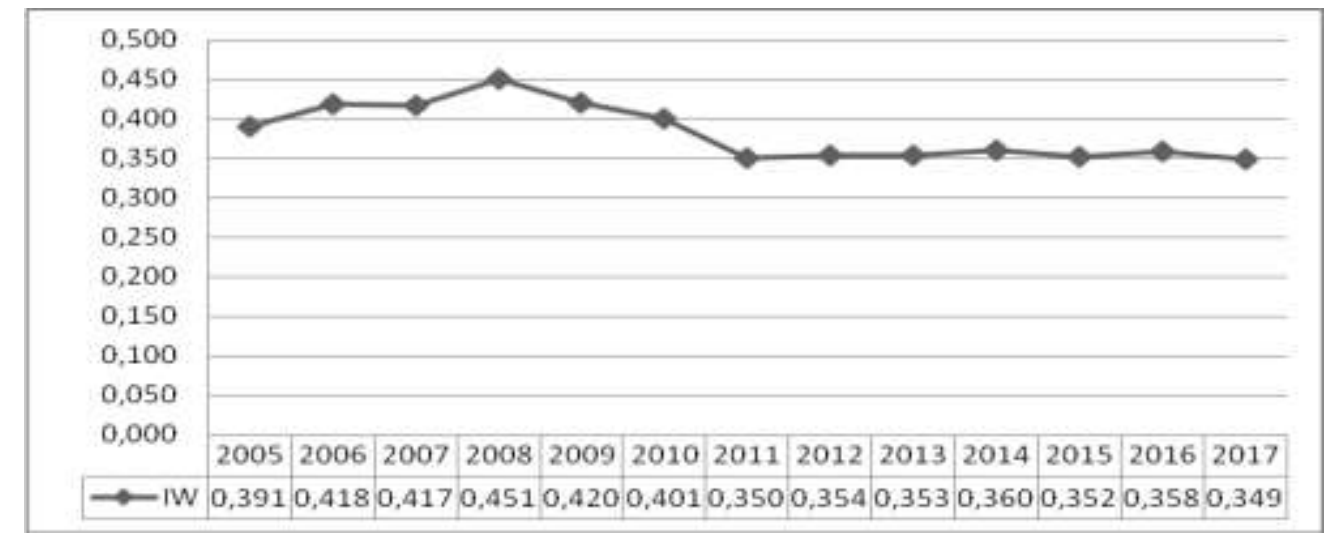

Sumber: BPS (2018), data diolah.

Pemerintah menyadari bahwa permasalahan mengenai ketidakmerataan distribusi pendapatan sangat berbahaya bagi perkembangan dan pembangunan wilayah. Oleh karenanya maka pemerintah berupaya untuk terus mengurangi kesenjangan pendapatan antar daerah yang terlihat dari kecenderungan indeks williamson yangg terus menurun. Hal ini menandakan bahwa setiap kabupaten/kota di Provinsi Bengkulu telah mampu melaksanakan pembangunan ekonominya dengan baik sehingga terjadi peningkatan PDRB di masing-masing kabupaten/kota setiap tahunnya. Meskipun jika dibandingkan antar kabupaten/kota, nilai PDRB masing-masing kabupaten/kota masih tercipta jarak cukup besar. Secara umum, Kabupaten Seluma merupakan kabupaten dengan nilai PDRB perkapita yang terkecil dari seluruh Kabupaten/kota, sementara Kota Bengkulu merupakan wilayah dengan tingkat pendapatan perkapita tertinggi di Provinsi Bengkulu. Nilai PDRB perkapita Kabupaten Seluma lebih kurang separuh dari pendapatan perkapita Kota Bengkulu. Walaupun terjadi peningkatan setiap tahunnya, namun posisi sebagai juru kunci dalam pencapaian PDRB terkecil belum dapat berganti dan jarak dengan daerah yang berpendapatan tertinggi tetap saja besar.

Pertumbuhan Ekonomi, Ketimpangan Pendapatan, dan Kesejahteraan Masyarakat Provinsi Bengkulu

Pertumbuhan ekonomi memiliki peran penting sebagai alat ukur keberhasilan pembangunan suatu daerah. Pertumbuhan ekonomi mencerminkan kemampuan suatu wilayah dalam menyediakan beragam jenis barang-barang ekonomi untuk masyarakatnya. Artinya semakin tinggi pertumbuhan ekonomi suatu wilayah maka akses masyarakat 
terhadap barang kebutuhannya menjadi semakin mudah. Kemudahan dalam pemenuhan kebutuhan hidup ini mendorong peningkatan taraf hidup masyarakat.

Namun, hasil empiris menunjukkan adanya arah pengaruh yang terbalik dan tidak biasa dari beberapa penelitian sebelumnya yang sudah dilakukan didaerah atau negara lain. Jika pada beberapa literatur menunjukkan pengaruh yang positif dan signifikan terhadap kesejahteraan masyarakat, seperti pada penelitian yang dilakukan oleh Mirza (2012) diwilayah Jawa Tengah yang menyatakan bahwa pertumbuhan ekonomi berpengaruh positif signifikan terhadap kesejahteraan masyarakat, artinya semakin meningkatnya pertumbuhan ekonomi maka semakin meningkat pula kesejahteraan masyarakat. Alur pikirnya adalah pertumbuhan ekonomi yang tinggi akan mendorong pencipataan pertumbuhan output perkapita dan daya beli masyarakat. Daya beli inilah yang menjadi salah satu indikator komposit dalam IPM yang disebut indikator pendapatan.

Akan tetapi dalam penelitian ini, pertumbuhan ekonomi berpengaruh secara signifikan dengan nilai yang negatif. Hal ini memberikan suatu fenomena yang menarik karena alur pikir pada umumnya terbantahkan, sifat hubungannya yang negatif dapat diterjemahkan bahwa pertumbuhan ekonomi merupakan hal yang mempengaruhi kesejahteraan masyarakat akan tetapi pertumbuhan ekonomi yang tinggi malah menyebabkan kesejahteraan masyarakat di Provinsi Bengkulu menurun, begitu pula sebaliknya, jika pertumbuhan ekonomi mengalami perlambatan maka akan mendorong kenaikan pada kesejahteraan masyarakat Provinsi Bengkulu. Hal ini dikarenakan masih terpusatnya pengelolaan sumber-sumber pendapatan pada kelompok atau individu tertentu. Sumber daya yang seharusnya dapat dinikmati oleh semua orang ternyata hanya dinikmati oleh segelintir saja. Investasi yang masuk di Provinsi Bengkulu belum mampu dinikmati oleh masyarakat secara menyeluruh. Ada beberapa daerah di Provinsi Bengkulu yang masih tertinggal pembangunannya dibanding daerah lainnya terutama daerah yang jauh dari pusat pemerintahan.

Arah pengaruh yang terbalik dari faktor pertumbuhan ekonomi ini dapat dikaitkan dengan hubungannya terhadap ketimpangan pendapatan antar daerah di Provinsi Bengkulu. Hasil empiris menunjukkan adanya hubungan yang positif dan signifikan antara pertumbuhan ekonomi dan ketimpangan pendapatan antar daerah di Provinsi Bengkulu. Hal ini semakin 
memperjelas kondisi pembangunan ekonomi di Provinsi Bengkulu. Meskipun pertumbuhan ekonomi yang dicapai tergolong tinggi namun disisi berbeda persentase penduduk miskin juga cukup tinggi. Arah pembangunan yang berorientasi pada pencapaian pertumbuhan ekonomi tinggi belumlah menjadi suatu kebijakan yang tepat jika tidak diiringi dengan pemerataan dari hasil pencapaian pertumbuhan ekonomi tersebut.

Pertumbuhan ekonomi yang semakin meningkat ternyata mendorong semakin lebarnya ketimpangan pendapatan antar daerah. Artinya kue pembangunan yang besar hanya dinikmati oleh sebagian kecil masyarakat. Hal inilah yang terjadi di Provinsi Bengkulu, sehingga perlu adanya perbaikan dalam kebijakan yang dilakukan. Perbaikan dalam tata kelola prioritas pembangunan akan sangat berdampak pada aspek pemerataan sehingga pertumbuhan ekonomi yang tinggi benar-benar dapat dirasakan dampaknya bagi masyarakat. Lebih lanjut, secara langsung ketimpangan pendapatan berpengaruh negatif dan signifikan terhadap kesejahteraan masyarakat di Provinsi Bengkulu. Temuan ini sama dengan yang dihasilkan oleh penelitian Abdel-Rahman dan Wang (1997) yang menunjukkan adanya hubungan negatif antara ketimpangan pendapatan antar daerah dengan kesejahteraan masyarakat, ketimpangan pendapatan antar daerah yang semakin melebar akan menurunkan tingkat kesejahteraan masyarakat.

Dari analisis pengaruh tidak langsung antara pertumbuhan ekonomi terhadap kesejahteraan masyarakat Provinsi Bengkulu melalui variabel intervening berupa ketimpangan pendapatan antar daerah ditemukan bahwa kesejahteraan masyarakat secara signifikan dipengaruhi secara tidak langsung oleh pertumbuhan ekonomi melalui ketimpangan pendapatan antar daerah sebesar 2 persen. Hal ini menandakan bahwa pertumbuhan ekonomi dapat memberikan pengaruh langsung dan tidak langsung terhadap kesejahteraan masyarakat Provinsi Bengkulu.

\section{KESIMPULAN}

Ketimpangan pendapatan antar daerah di Provinsi Bengkulu yang diukur melalui indeks williamson selama periode 2005-2017 cenderung berfluktuasi dengan tren yang menurun. Pada tahun 2005, ketimpangan pendapatan yang terjadi di Provinsi Bengkulu adalah sebesar 0,39 dan mengalami kenaikan tertinggi pada tahun 2008 senilai 0,45, namun dapat 
ditutup dengan angka rendah di tahun 2017 yaitu sebesar 0,36. Ketimpangan pendapatan rata-rata antar daerah di Provinsi Bengkulu dalam rentang periode tersebut adalah 0,38 yang berarti ketimpangan pendapatan yang terjadi di Provinsi Bengkulu termasuk dalam kategori sedang.

Pertumbuhan ekonomi berpengaruh positif dan signifikan terhadap ketimpangan pendapatan antardaerah. Ketimpangan antar daerah berpengaruh negatif dan signifikan terhadap kesejahteraan masyarakat, begitu pula dengan pertumbuhan ekonomi, yang memiliki pengaruh negatif terhadap kesejahteraan masyarakat Provinsi Bengkulu. Pertumbuhan ekonomi berpengaruh tidak langsung terhadap kesejahteraan masyarakat Provinsi Bengkulu melalui ketimpangan pendapatan antar daerah. Hal ini dapat juga diartikan bahwa ketimpangan pendapatan antar daerah merupakan variabel mediasi bagi pertumbuhan ekonomi dalam mempengaruhi tingkat kesejahteraan masyarakat di Provinsi Bengkulu.

\section{KETERBATASAN DAN REKOMENDASI}

Penelitian ini mengkaji kesejahteraan di Provinsi Bengkulu dengan menggunakan rentang data yang cukup singkat, untuk melihat lebih detil kondisi kesejahteraan masyarakat sebagai imbas dari membaiknya indikator makro dan pembangunan ekononomi yang telah dilakukan, maka perlu memperpanjang waktu pengamatan dan penambahan variabel yang berperan dalam mempengaruhi tingkat kesejahteraan masyarakat di Provinsi Bengkulu.

Dari hasil temuan dalam studi ini dapat dimunculkan sebuah rekomendasi bagi pihak yang berkepentingan yaitu dalam pembangunan ekonomi sebaiknya tidak hanya mengejar pertumbuhan ekonomi yang tinggi namun juga memeratakan pendapatan antar daerah sehingga kesenjangan dapat diminimalisir.

\section{DAFTAR PUSTAKA}

Abdel-Rahman, Hesham., dan Wang, Ping. (1997). Social Welfare and Income Inequality in a System of Cities. Journal of Urban Economics, 41, 462-483.

Anwar A. (2005). Ketimpangan Wilayah dan Pedesaan: Tinjauan Kritis. Bogor: P4W Press.

Arsyad, Lincolin. (2010). Ekonomi Pembangunan. Yogyakarta : Penerbit STIM YKPN.

BPS. Provinsi Bengkulu Dalam Angka. (2018). Bengkulu: BPS. 
Chang, J. Y., Ram, R. (2000). Level of Development, rate of Economic Growth and Income Inequality. Economic Development and Cultural Change, 48(4), 787-799.

Kuncoro, Mudrajad. (2010). Dasar- dasar Ekonomika Pembangunan. Yogyakarta : UPP STIM YKPN.

Kuznets, Simon. (1955). Economic Growth and Income Inequality. The American Economic Review, 45 (1), 1-28.

Lanjouw, P., M. Pradhan, Saadah, H. Sayed, R. Sparrow. (2001). Poverty, Education and Health in Indonesia: Who Benefits from Public Spending? World Bank Working Paper No. 2739. Washington D.C.: World Bank.

Mirza, Denni Sulistio. (2012). Pengaruh Kemiskinan, Pertumbuhan Ekonomi, dan Belanja Modal terhadap Indeks Pembangunan Manusia di Jawa Tengah 2006-2009. Jurnal Ekonomi Pembangunan, 1, 1-15.

Oates, W. (1993). Fiscal Decentralization and Economic Development. National Tax Journal, 46 (2), 237-243.

Riduwan dan Achmad Kuncoro, Engkos. (2008). Cara Menggunakan dan Memaknai Path Analysis (Analisis Jalur). Bandung: Penerbit Alfabeta.

Sarel, Michael. (1997). How Macroeconomic Factors Affect Income Distribution: The Cross-Country Evidence. IMF Working Paper No. 152.

Sarwono, Jonathan. (2010). Analisis Jalur Untuk Riset Bisnis dengan SPSS Edisi 5. Yogyakarta: Penerbit Andi.

Sjafrizal. (2008). Ekonomi Regional Teori dan Aplikasi. Padang : Penerbit Baduose Media.

Streiner, David L. (2005). Finding Our Way: An Introduction to Path Analysis. Can J Psychiatry, 50 (2), 115-122.

Todaro, Micheal P dan Stephen C. Smith. (2012). Economic Development 11th edition. United States of America : Pearson.

UNDP. (2000). Human Development Report. New York: United Nation.

Xu, L. C., Zou, H. (2000). Explaining the Changes of Income distribution in China. China economic Review, 11 (2), 149-170. 